А.М.Лямець.

молодший науковий співробітник Відділу бібліотечних зібрань та історичних колекиій Начіональної бібліотеки України імені В.І. Вернадського

Т.А.Якубова, кандидат історичних наук, науковий співробітник Відділу бібліотечних зібрань та історичних колекцій Національної бібліотеки України імені В.І.Вернадського

\title{
МАТЕРІАЛИ ПРО ФОМУ АКВІНСЬКОГО (1225 АБО 1226- 1274) У ПОЛЬСЬКОМОВНОМУ ТА ФРАНКОМОВНОМУ ФОНДАХ ВІДДІЛУ БІБЛІОТЕЧНИХ ЗІБРАНЬ ТА ІСТОРИЧНИХ КОЛЕКЦІЙ НБУВ
}

28 січня 2015 р. виповнилося 790 років 3 дня народження Фоми Аквінського, відомої постаті європейського середньовічного світу. Фома Аквінський (Фома Аквінат, Тома Аквінський, Thomas Aquinas) (1225 або 1226-1274) - видатний філософ, схоластик та теолог Середньовіччя. Народився в замку Рокказекка (Італія). У 1239-1243 рр. вчився в Неапольському університеті, а 1245 р. прийняв обітницю монаха Домініканського ордену. Поділяв домініканську філософську доктрину. Водночас його ім'я пов'язане також $з$ діяльністю францисканців.

В Україні ім'я Фоми Аквіната є загальновідомим. Видатна історична постать фундатора вчення томізму, яке в наш час трансформувалося у неотомізм, лишається досі актуальною для наукових книгознавчих, історичних, філософських, богословських досліджень. Його викладацька та теологічна діяльність відзначена в широких світських колах усієї Європи, зокрема в Кельні, Парижі, Римі. Раціоналістичні позиції теолога щодо роз'яснення богословських питань виходили далеко за межі його часу.

Святому Фомі вдалося примирити погляди давньогрецьких філософів 3 офіційною теологічно-філософською доктриною католицизму часів догматичних дискурсів раннього Середньовіччя.

Вчення Святого Фоми еволюціонувало, набравши філософських 
аспектів універсалізму, синтезу та прагнення наблизитися до божественної досконалості. Зокрема, в ньому було визначено проблеми неотомізму як філософії. В Україні неотомізм розвивається завдяки тенденціям релігійної толерантності в сучасному українському соціумі. Підтвердженням цього $є$ існування та діяльність Інституту релігійних наук Св.Томи Аквінського в Києві, який є вищим римо-католицьким богословським навчальним закладом.

До основних праць Фоми Аквіната належать - «Сума теології» (Summa Theologica) та «Сума проти язичників» (Summa contra Gentiles), в яких він аналізує сучасні йому богословські проблеми, висуває п'ять фундаментальних доказів існування Бога. Крім того, серед його творів вирізняються богословські синтези (Scripta super libros Sententiarum -Коментар до «Сентенцій» Петра Ломбардського», університетські лекції De veritate (1256-1259) («Про істину»), De potentia Dei (1259-1268) («Про Божу могутність»), De spiritualibus creaturis (1269) («Про духовні створіння»), De anima (1269-1270) («Про душу») та ін.), коментарі до Святого Писання (Expositio in Job ad litteram (1260) («Коментар до книги Йова»), In Psalmos Davidis expositio (1272-1273) («Коментар до Книги Псалмів»), Expositio in Canticum Canticorum («Коментар до Книги Пісні Пісень»), Expositio in Isaiam prophetam (1256-1259) («Коментар до Книги Пророка Iсаї»), коментарі до творів Арістотеля (In libros Peri Hermeneias expositio (1269-1271) «Коментар до Книги «Пояснення»», In libros posteriorum Analyticorum expositio (1268) («Коментар до книги «Аналітика II»»), In octo libros Physicorum expositio (1268-1271) («Коментар до восьми книг «Фізики»»), In libros De caelo et mundo expositio (1272-1273) («Коментар до книги «Небеса та світ»» та ін.), полемічні твори (Contra impugnates Dei cultam et religionem (1256) («Проти тих, хто виступає проти Божого культу та релігії»), De perfectione vitae spiritualis (1270) («Про досконалість духовного життя»), Contra pestiferam doctrinam retrahentium pueros a religionis ingressu (1270) («Проти згубного вчення, що відволікає молодь від вступу до монастиря»), De unitate intellecuts, contra Averroistas (1270) («Про єдність інтелекту. Проти авероїстів») та ін.), трактати та коментарі на особливі теми (De fallaciis ad quosdam nobiles artistas (1244-1245) («Про обман деяких відомих артистів», De propositionibus modalibus (1244-1245) («Про модальні твердження») та ін., листи, літургійні твори та проповіді.

Фома Аквінський відзначався тим, що, незважаючи на духовний 
сан, цікавився давньогрецькою філософією (зокрема, Арістотелем), а згодом адаптував його трактати до розуміння схоластичного світу. Фому не цікавили лише онтологічна складова доведення існування Бога (Августін Блаженний) та догматичні теорії - він покладався на системні, часто діалогічні, побудови раціоналістичних тверджень. За його існування релігія фактично стала системною, енциклопедичною та логічною наукою, зорієнтованою не тільки на прибічників віри, а й на всіх, хто прагне знань. Особливістю є те, що свої доведення існування Бога та проповіді він адаптовував i для розуміння язичників, які через брак знань не могли повноцінно використовувати поняттєво-філософські концепти католицизму.

У своїй найвизначнішій праці «Summa theologica», що поділяється на три частини (перша розповідає про Бога, друга - про людину, третя - про втілення Бога на землі), Фома значною мірою відходить від схоластичної теології і проявляє себе також як досвідчений філософ та викладач (цитує Арістотеля, Августіна Блаженного, арабських та язичницьких мислителів).

В Національній бібліотеці України імені В. І. Вернадського були проведені книгознавчі та бібліографічні дослідження праць Фоми Аквінського у фондах Відділу бібліотечних зібрань та колекцій. Для реалізації більшої обізнаності про праці великого теолога та філософа були залучені одночасно польські, німецькі та французькі фонди, в тому числі довідкові. Відділом стародруків та рідкісних видань НБУВ були надані палеотипи творів Фоми. Була зібрана бібліографія щодо біографії Фоми Аквінського, в якій значна кількість першоджерел становить науковий інтерес.

Зібрана бібліографія являє собою бібліографічну довідку (див. Література (Додаток 1))., що була використана в читальному залі Відділу бібліотечних зібрань та історичних колекцій для формування книжкової виставки «790 років від дня народження Фоми Аквінського (1225 або 1226-1274), середньовічного філософа і теолога» (1-20 лютого 2015 р.). Зокрема, на виставку було запропоновано 8 джерел польського періодичного видання Biblioteka dzieł Chrześcijańskich: Cathrein S.J. Filozofia moralności [5, 8]; Hergenröther J. Historya Powszechna Kościoła Katolickiego [9, 135]; Bqczek X.J. Zarys historyi filozofii [3, 90-95]; Schanz P. Apologia chrześcijaństwa [11, 5-24]; Wais K. Kosmologia ogólna [21, 14-15] та ін. Особливістю польськомовних статей $\epsilon$ те, що вони містять наукове осмислення теологічних та філософських праць Фоми Аквінського. Окрім періодики, 
на книжковій виставці Відділу бібліотечних зібрань та історичних колекцій було подано статтю про Фому Аквіната з польських та французьких універсальних енциклопедій: Tomasz d'Aquine [19], Tomasz z Akwinu [20], Thomas D’Aquin [7]. Низка праць самого Фоми Аквінського - мовою оригіналу: D. Thoma Aquinatus. Quaestiones theologicae selectae [8]; Rationale theologicum [10]; Thomas Aquin. Commentariorum... [12]; Thomas Aquinas. Doctrina Angelici... [13]; Thomas de Aquino. Opuscula Sancti Thome... [16] та ін.

Відділ стародруків та рідкісних видань НБУВ запропонував для виставки низку палеотипів: Thomas de Aquino (1225-1274) Commentaria... in Epistolas Pauli [15]; Thomas de Aquino (1225-1274). Summa sacrae theologiae [17].

Під час формування виставки використовувались службові та читацькі каталоги Відділу бібліотечних зібрань та історичних колекцій НБУВ: Систематический каталог Киево-Печерской Лавры 1908 г., Т. I (Богословие) та франкомовні довідкові і бібліографічні видання XVIII-початку XX ст. з фондів цісї самої бібліотеки.

Розглянемо докладніше джерела польського фонду Відділу бібліотечних зібрань та історичних колекцій НБУВ.

С.Й.Катрейн у «Філософії моральності» $[5,151]$ аналізує погляди Фоми Аквінського на особливу систему права, що має назву ius gentium («право народів», термін, що виник ще в Давньому Римі). Правові норми ius gentium стали частиною римського законодавства у вирішенні суперечок між римськими громадянами та іноземцями (перегрінами). Основною його особливістю $є$ нівелювання дискусійних аспектів цивільного права і пристосування до потреб купецького обміну (пришвидшення торгівельних операцій). Святий Фома погоджується 3 римськими правознавцями щодо основних постулатів та правових норм. Він розуміє ius gentium як частину позитивного права, що виникла з природного права, тому, мовляв, під час реалізації його слід зважати на його подвійне походження. Філософсько-правовий дискурс С.Й.Катрейна засвідчує, що деякі погляди Фоми Аквінського на право інтерпретовані як схожі з соціалістичними. Однак середньовічний філософ вважав, що приватна власність належить саме до ius gentium i підтримується позитивним правом (що за певних умов може змінюватися, адже це закони людські). Дискусійні соціалістичні інтенції, що їх приписують Фомі, не збігаються $з$ його власною інтерпретацією ius gentium в Сумі теологіï, де він зазначає: «еst de ratione legis humanae, quod sit derivata 
a lege naturae... et secundum hoe dividitur ius positivum in ius gentium et civile» $[5,152]$. Тобто «в розумінні людського права, що виникло з природного ... позитивне право поділяється на ius gentium та ius civile». Тож, якщо до ius gentium належить приватна власність, то, згідно з Сумою теології, це означає, що така форма власності походить від позитивного права, яке, своєю чергою, виникло з природного. У підсумку виходить, що приватна власність, за поглядами Фоми Аквінського, є природною. Як бачимо, науковий доробок Фоми Аквінського в сфері вивчення філософської основи правових питань $\epsilon$ цінним та фундаментальним.

Й.Хергенрьотер, німецький католицький богослов, кардинал, прибічник ідеї непогрішності Папи Римського, в «Загальній історії католицької Церкви» $[9,139]$ звертає увагу на те, що над питаннями систематизації ідей Арістотеля ще до Фоми Аквінського працював Святий Бонавентура (1221-1274). Фому він характеризував як «największy ze scholastyków» (найвидатніший схоластик), «stąd księciem szkoły» (став фундатором вчення) і цьому є певне пояснення. Порівнянно з Бонавентурою, цей дослідник займався синтезом арістотелізму та августинізму, а внутрішньому спілкуванню людини з Богом, ірраціональності августинізму протиставляє злагоджену систему доказів та догматів, що можна було осмислити раціональним шляхом. Святий Фома продовжив традицію систематизації догматичної богословської думки Середньовіччя, розпочату в magnum opus Петра Ломбардського (?-1160) «Сентенції». Важливим показником різнобічного осмислення суті буття Фомою вважається його значний вплив і в світському житті (його високо цінували Людовик IX, Урбан IV, Григорій Х та ін.). Й. Хергенрьотер вирізняє три найважливіші, на його думку, праці Аквіната: Суму католицької віри проти язичників (в 4-х томах), в якій обстоюються постулати філософії релігії, або філософії одкровення, Коментарі до 4-х книг Сентенцій Петра Ломбардського, Суму теології в 3-х частинах (3 частина залишилася недописаною, однак ії можна було доповнити з Коментарів до Сентенцій). У Сумі теології Фома систематизував погляди Августина Блаженного Аврелія, використовував докази існування Бога Ансельма Кентерберійського, ідеї Петра Ломбардського та ін. Згідно з Й. Хергенрьотером, Фома Аквінський, застосовуючи індуктивні логічні методи (від часткового до загального) та досвід попередників, сформулював раціональні докази існування Бога, логічно підніс авторитет Священного Писання, колек- 
тивний та індивідуальний містичний досвід до раціональної наукової системи (низка його попередників орієнтувалася на містичний досвід та авторитет Священного Писання як на нераціональні докази).

Е.Васман у «Сучасній біології та теорії розвитку» [24, 11-12] згадує Фому Аквінського серед представників схоластики, що були фахово підготовлені та мали наміри здійснити самостійні наукові розвідки, в тому числі і в сфері вивчення природи. Серед них - Фома з Шантімпре, Вінсент з Бове та, особливо, Альберт Великий. Вплив Альберта Великого, автора природничонаукових трактатів про рослини і тварин, на світогляд його учня Фоми Аквінського є беззаперечним. Саме від нього Святий Фома навчився проводити власні дослідження на основі спостережень і досвіду. Хоча він не був фахівцем з біології, біологічна модальність Арістотеля та Альберта Великого дали йому змогу осмислювати філософські концепції від нижчих ієрархічних ступенів до вищих.

К.Вайс у «Загальній космології» [21, 14-15] виокремлює «тріаду» схоластиків: Альберта Великого (1193-1280), Фому Аквінського (1225-1274) та Дунса Скота (1275-1309). Саме вони не тільки пояснювали космологічні концепції перипатетиків, але й вдосконалили та збагатили їх, системно осмисливши в спектрі католицької віри. К. Вайс аналізує погляди критиків схоластичної філософії, які звертали увагу на несистемні знання іï представників 3 фізики та природничої історії. Фактично філософи та теологи Середньовіччя знали фізику та природничі науки в межах своєї освіти та тих соціальних умов, в яких вони жили. Середньовічна схоластика не була епохою «динаміки», прогрес ії еволюційного руху був досить поступовим, тому й знання $з$ фізики накопичувалися доволі епізодично. Слід зауважити, що несистемні підходи нівелювалися досягненням стабільності наукового аналізу, поступовим збагаченням цінної інформації, формуванням космологічних фундаментальних істин, які були не відомі з часів Давньої Греції. 3 іншого боку, грунтовне вивчення трактування природничих наук Арістотелем давало змогу філософам вийти на якісно вищий рівень наукового сприйняття. К. Вайс аргументує, що природничий аспект не лишався осторонь уваги визначних філософів. Зокрема, Фома Аквінський присвятив цим питанням окремі трактати. Він не тільки коментував Фізику та Метеорологію Арістотеля (книги Арістотеля De coelo et mundo, De generatione et corruptione), але й написав оригінальні праці (De mixtione elementorum, De occultis naturae operibus), 
в яких аналізуються змішування і об'єднання елементів та вплив на них фізичних сил. У творі Quaestiones disputatae він полемізує про світло як про явище, що пов'язане з рухом. Космологічні та природничі погляди Фоми спонукали до раціонального орієнтування та теоретизування наукової думки Середньовіччя, до опанування жанрів сум (компендіумів). Надалі це посприяло розвитку енциклопедичності природничих дисциплін.

К.Дебінський у «Практичному керівництві до пасторської теології» $[6,40]$ цитує Фому Аквінського не тільки як теологічного теоретика, але й практика, який зауважує щодо загальних вимог до пасторських якостей. К.Дебінський висловлює думку, що пастор повинен на належному рівні оповідати слово Боже. Крім того, він має чітко, зрозуміло розповідати Свангеліє і орієнтувати людей на використання здобутих знань у житті. Якщо священик не має такого дару чи має проблеми з вимовою, він не має бути пастором. Зокрема, щодо цих якостей та дарувань Святий Фома зазначає, що якщо Бог хоче бачити людину на якомусь місці, він обдаровує іiі тими необхідними здібностями, котрі від неї вимагаються. Коментарі Фоми щодо пасторської діяльності переконують у його системному баченні теологічних питань, прагненні осмислити педагогічні підходи до навчання священика, можливості через теоретичні умовиводи робити практичні висновки та вирізняти серед них головне. Хоча для нашого часу його педагогічні доктрини $є$ досить категоричними, не слід забувати, що в добу схоластики такі підходи формували підкатегорії якості та ефективності, визначення професійних схильностей людини.

Й.Бачек у «Нарисі історії філософії» [3, 90-95] звертає особливу увагу на те, що найбільш фундаментальними дослідженнями святого Фоми щодо праць Арістотеля є коментарі до книг «Peri hermeneias» (Про тлумачення), «Analitykę drugą» (Друга Аналітика), «Metafizykę» (Метафізика), «Fizykę» (Фізика), «O drobnych rzeczach w przyrodzie» (Про малі речі в природі), «O duszy» (Про душу), «Etykę Nikomachijską» (Нікомахова етика), «Polityke» (Політика), «Księgi o meteorach» (Метеорологіка), «O niebie i świecie» (Про небо), «О rodzeniu i zepsuciu» (Про виникнення і знищення) та ін. Згідно 3 поданими відомостями стає очевидним, що Фома досконало знав праці давньогрецького філософа і відпрацював фундаментальний філософський науковий базис для розуміння його поглядів. «Висока» схоластика Фоми Аквінського проявила себе в аналітичних 
роздумах про можливості звернення західної католицької церкви до давнього наукового надбання людства без втрати фундаментальних догматів віри. Для цього святий Фома мав розуміти, що його теологічно-філософські роздуми мають грунтуватися на системі, яка вміщуватиме науково-поняттєвий апарат, досі не властивий католицьким дослідникам. Аналітичні підходи об'єднання та роз'єднання складових будь-якої системи дозволили Фомі сформувати свою наукову аргументацію, відштовхуватися від найменших величин до найбільших, від окремих поняттєвих елементів - до доказів існування Бога, від нейтральних речень - до текстів, що можуть вважатися істинними або хибними.

П.Шанц в «Апології християнства» $[11,5-24]$ висвітлює космологічні та телеологічні аспекти доказів існування Бога. Причому диференціювання доведення мало б відбуватися від неорганічного світу до органічного, від рослини - до тварини, від тварини - до людини. П.Шанц рекомендує розглядати насамперед п'ять доведень існування Бога Фомою Аквінським. У них Святий Фома керується принципами Арістотеля, зокрема виходить із твердження, що доказ формує знання, а знання також можна здобути з очевидних положень, які, своєю чергою, можна здобути за допомогою силогізмів. Отже, низку християнських основ та догматів Фома Аквінський зміг обгрунтувати за допомогою причинно-наслідкових аргументацій. Деякі 3 проміжних висновків, зокрема безумовні очевидні істини або реалії, не потребували об'єктивного доведення, що полегшувало роботу з трактування богословських проблем. Безумовні істини репрезентувалися за допомогою аналізу тієї інформації, що надходила до людини через рецептори органів відчуття (зір, слух, дотик, нюх, смак і т.д.). Внаслідок врахування можливості побудови богословських доведень на положеннях очевидних істин онтологічні докази існування Бога довгий час вважалися найприйнятнішими.

Базуючись на поглядах неосхоластиків (В.Акерман та П.Раджей) (W.Ackermann, P.Ragey), П.Шанц доходить висновку, що спіритуалізм Платона, Арістотеля, Фоми Аквінського, Декарта та Г.В.Лейбніца можна висловити тезою: «Досконалість - необхідна, недосконалість - випадкова». Якщо розум людини розвивається від недосконалості до досконалості, то в підсумку досконалість має привнести полегшення та щастя, а це вже не потребує подальших доведень. Існували й інші погляди. Зокрема, Ансельм Кентерберійський вважав, 
що принцип досконалості буття, в своєму найвищому прояві, привносив духу людини спокій. Святий Фома, продовживши традицію діалектики Арістотеля, також зазначає, що єдність божественної природи, відповідно до поглядів віруючих, - це єдність всемогутності та всеобізнаності (досконалості) Бога, що є феноменом недемонстративного пізнання, а віри. Однак сам факт існування ієрархічного руху від недосконалих форм (людини) і до найвищих Фома Аквінський трактує як один із доказів (Четвертий доказ) божественного існування (має існувати найдосконаліша форма в ієpapxiї, і нею є Бог).

Розглянемо докладніше довідкові джерела. Енциклопедія С. Оргельбранда Encyklopedia Powszechna [20, 522] доповідає, що Фома Аквінський був учнем Альберта Великого, визначного схоластика Середньовіччя, який коментував філософські праці Арістотеля та арабських вчених. Крім того, Альберт Великий написав трактат, що мав назву Summa theologiae. Святий Фома продовжив наукові дослідження свого вчителя, теоретично аргументувавши можливість виведення 3 тез Арістотеля філософсько-теологічних принципів католицизму, розглянувши праці давньогрецьких та арабських учених у світлі своїх наукових досліджень. Особливу увагу слід звернути на той факт, що Фома Аквінський досяг значного успіху в середньовічному історичному джерелознавстві. Ще один важливий факт на користь цього твердження - замість арабських перекладів Арістотеля (переклади так званих аверроїстів) він давав перекладачам давньогрецькі першоджерела і використовував саме їх.

Важливу роль у житті Фоми Аквінського відіграв Папа Римський Урбан IV, за проханням якого було написано трактат «Contra errores graecorum» (Проти помилок греків). Як і в інших своїх твоpax, Фома коментує та доводить невідповідність між поглядами східних грецьких богословів та західних (традиційних) схоластиків досить виважено. Фундаментальність його досліджень підкреслюється фундаментальністю поставлених завдань. Якщо в Сумі теології він наводить п'ять аргументів існування Бога, то в Contra errores graecorum Святий Фома аналізує чотири основних питання, що стали причиною розколу між східною та західною церквами (джерело та спосіб ісходження Святого Духа, пріоритет єпископа Рима порівняно 3 іншими єпископами християнської церкви, використання квасного хліба для причастя, вчення про чистилище). Окрім основних проблем середньовічної теології, Фома, як і Альберт Великий, ввів у 
тогочасний науковий обіг доповнене та переосмислене вчення Арістотеля. Відтак західна католицька церква дістала можливість системно засвоїти основні принципи давньогрецької та арабської філософії (погляди представника арабського арістотелізму Абу льВаліда Мухаммеда ібн Ахмеда ібн Рушда, або Аверроеса).

У довідковому джерелі Encyklopedya powszechna [19, 678] досліджуємо інший бік наукової та освітянської роботи Фоми Аквінського. Як зазначено, вчений ступінь святого Фоми Doctor universalis aбo Doctor angelicus є заслуженою та високою відзнакою його наукових досліджень. Проаналізуємо, за які досягнення можна було в Середньовіччі отримати ступінь Doctor universalis. Як вже ми зазначали раніше, Святий Фома фактично продовжив традицію пізнання світу давньогрецького філософа та вченого Арістотеля, який мав, без перебільшення, енциклопедичний рівень знань. Тому не випадково, що Фома Аквінський перейняв низку діалектичних, логічних та філософсько-пізнавальних підходів давніх греків. Він прагнув, як і Арістотель, різнобічно проаналізувати світ, однак зробив це вже через призму схоластично-середньовічної думки (так званої «високої схоластики»), яка оперувала вже складнішим логічним та поняттєвим апаратом. Охопивши всебічну систему середньовічної філософіï, збагативши їі ідеями та досягненнями давньогрецького та арабського світу, він досяг рівня «universalis» - всестороннього вченого, а католицька церква додала до цього титулу ступінь «angelicus» (ангельський, найвищий) - за вірність ідеалам католицизму.

У Dictionnaire de la Conversation et de la lecture [14] досліджується складна система впливу Фоми Аквінського на історичних осіб його часу. Це пояснюється його знатним родоводом. Для прикладу, на одній з промов 1615 р. кардинал Дю Перрон зазначає, що Святий Фома був родичем Людовика Святого (Людовика IX). I це, незважаючи на те, що сам по собі рід Аквінів був знаним (Фома Аквінський був сьомим сином графа Ландольфа Аквінського). Проте $з$ певних причин Фома відсторонювався від аристократичного життя та високих посад. Керуючись канонами Святого Домініка (Домініка де Гусмана), він більше тяжів до наукового життя та усамітнення. Це не виключає його значного духовного та політичного впливу на короля Франції Людовика IX та низки кардиналів. Отже, Фома Аквінат стає не тільки теологом та філософом, але й політичним радником.

Низка використаних джерел про Фому Аквінського має озна- 
ки приналежності до колекцій. Зокрема, були зафіксовані такі провенієнції: у енциклопедії Encyklopedia Powszechna [20] - печатка Бібліотеки музею м. Біла Церква, датована 1947 р.; у виданні Encyklopedya powszechna Adama Wiślickiego [19] - печатка Центрального Волинського музею в Житомирі; досліджені провенієнції у продовжуваному виданні Biblioteka Dzieł Chrześcijańskich, зокрема печатка «Praelatus Cap Theophilus Skalski. Protonotarius Apostelicus ad instar» [5]; печатка Бібліотеки музею Бердичева, печатка Музею Бердичівщини [3]; печатка Ksiądz Jan Nazarewicz [11] [21].

Матеріали про Фому Аквінського, наявні у Відділі бібліотечних зібрань та історичних колекцій Національної бібліотеки України ім. В.І.Вернадського, дозволяють здійснювати подальші книгознавчі, філософські та теологічні дослідження. Їх важливість для науки зумовлена різнобічною концепцією наукової діяльності Святого Фоми, яку можна подати схематично.

Схема 1. Концепція наукової діяльності Фоми Аквінського

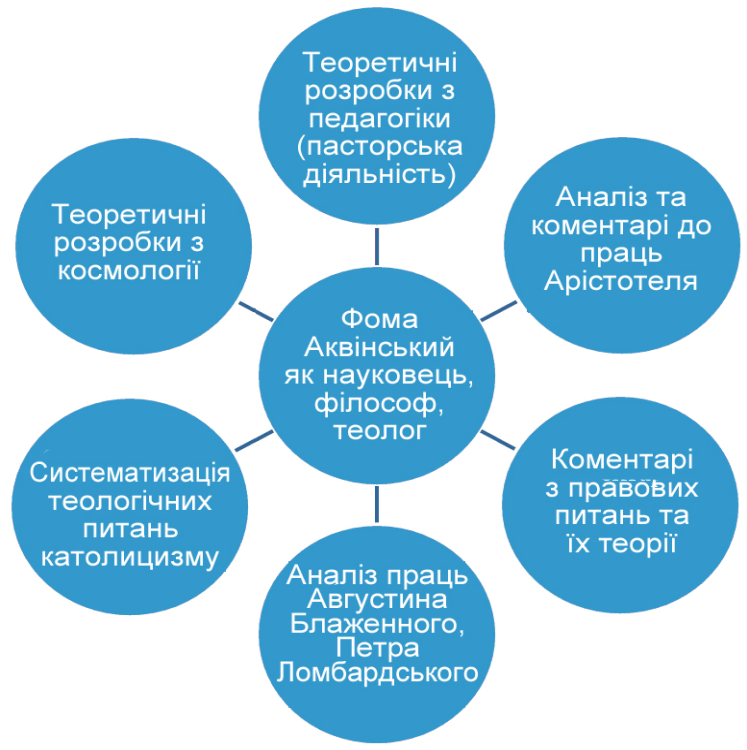

Роль Фоми Аквінського в європейській історії можливо вважати прогресивною в плані примирення концептів - наука та релігія, діалектика та схоластика, логіка та божественне одкровення, давньогрецька філософія та ортодоксальна католицька філософія. 
Актуальність неотомізму в Україні в умовах духовної кризи зумовлена гуманістичною сутністю головних теологічних ідей. Це - гармонія віри та розуму, інтелектуальна інтерпретація істин одкровення, новий тип міжлюдських зв'язків - солідаризм, базований на любові до ближнього, розвиток в особистості божественного начала.

\section{ЛІТЕРАТУРА.}

1. Систематический каталог Киево-Печерской Лавры 1908 г. Т.І (Богословие) / Печатано по распоряженію Духовнаго Собора Лавры. - Кіевъ, 1908. - C. 102, 134, 145.

2. Франкомовні довідкові та бібліографічні видання XVIII - початку XX ст. у фондах Національної бібліотеки України імені В.І.Вернадського: каталог / Уклад. М.А.Стельмашева, А.М.Беба, Р.С.Кириченко; НАН України. Національна бібліотека України імені В.І.Вернадського. - К., 2008. - 272 с.

3. Bqczek X.J. Zarys historyi filozofii // Biblioteka Dzieł Chrześcijańskich. [Warszawa: Skład G łowny w Ksiegarni Gebethnera i Wolffa]. - 1909. Zeszyt 106. - S.90-95.

4. Cathrein S.J. Filozofia moralności: Tom I // Biblioteka Dzieł Chrześcijańskich. - [Warszawa: Skład Głowny w Ksiegarni Gebethnera i Wolffa]. 1904. - Zeszyt 38. - S. 53, S. 112-113, S. 198-201.

5. Cathrein S.J. Filozofia moralności: Tom II // Biblioteka Dzieł Chrześcijańskich. - [Warszawa: Skład Głowny w Ksiegarni Gebethnera i Wolffa]. 1904. - Zeszyt 39. - S.8, S.33-34, S.45-46, S. 151-155.

6. Dębiński K. Podręcznik praktyczny Teologii Pasterskiej: Tom I // Biblioteka Dzieł Chrześcijańskich. - [Warszawa: Skład Głowny w Ksiegarni Gebethnera i Wolffa]. - 1914. - Zeszyt 159 i 160. - S.40.

7. Thomas D'Aquin // Dictionnaire Universel des noms propres: alphabétique et analogique: Tome IV: Q-Z / Sous la direction de Paul Robert. Société du Nouveau Littré, Dictionnaire Le Robert, 1974. - P. 472.

8. D. Thoma Aquinatus. Quaestiones theologicae selectae. Calissii. 1681. $4^{0}$. V 6/142.

9. Hergenröther J. Historya Powszechna Kościoła Katolickiego: Tom VIII // Biblioteka Dzieł Chrześcijańskich. - [Warszawa: Skład Głowny w Ksiegarni Gebethnera i Wolffa]. - 1902. - Zeszyt 19. - S.135, S. 139-145, S.156-157.

10. Rationale theologicum Deo et Mariae Sacrum ex summa D. Thomae praeceptoris angelici depromptum Thomistice quoque in studio conventus Varsav: S. Martini ord. erem. S.P.Augustini Praelectum. Publicae Concertationi in comitiis provincialibus. Brestal. 1691. $4^{0}$. III 5/56.

11. Schanz P. Apologia chrześcijaństwa // Biblioteka Dzieł Chrześcijańskich. [Warszawa: Skład Głowny w Ksiegarni Gebethnera i Wolffa]. - 1905. - Zeszyt 59. - S.5-24. 
12. Thomas Aquin. Commentariorum ac disputatio num in tertiam partem divi Thomae. T.2. Venetis, 1604. $\mathrm{F}^{0}$. (Экз. непол.) XVI 2/9.

13. Thomas Aquinas. Doctrina Angelici Doctoris Divi Thomae Aquinatis de Spiritus Sancti à Filio processione. Pars. 1-2. Lublin, 1694. $4^{0}$. V 6/155.

14. Thomas d'Aquin // Dictionnaire de la Conversation et de la lecture [TenVed] / Belin-Mandar. - München: Belin - Mandar, 1839. - 492 S. I3 ФP B137/51-52 1839 .

15. Thomas de Aquino (1225-1274) Commentaria... in Epistolas Pauli / Thomas de Aquino. - Paris: apud Johannem Petit, per Francis cum Regnaut impressorem, 1529. - [14], 236 f.; $2^{0}$. Pal. 237. (Відділ стародруків та рідкісних видань НБУВ).

16. Thomas de Aquino (1225-1274). Opuscula Sancti Thome: quibus alias impressis nuper hac addidimus. V[delicet] Summa(m) totius logice. Traktatum celeberrimum de Vsuris nusq[ue] alias impressum / Thomas de Aquino; [Praef: Antonius Pizzamanus]. - Venetiis [Venezia]: expens. Petri Liechtenstein, cura Jacobi Pencio, $15 \mid$ 1508. - 306 f.: $2^{0}$. Pal 1759.

17. Thomas de Aquino (1225-1274) [Summa sacrae theologiae. P.I. 1-2] / Thomas de Aquino. - Venetiis [Venezia]: per Philippum Mantuanus, expens. Giuntini de Giunta Florentini, 23 IV 1509. - 148 f.; $2^{0}$. Pal. 34. (Відділ стародруків та рідкісних видань НБУВ).

18. Thomas de Aquino (1225-1274). Super epistolas Pauli Commentaria... / Thomas de Aquino. - Parrhisiis [Paris]: impressa cura Andreae Boucard. imp. Johannis Petit, $20 \mid$ 1518. - [14], CCLX [=260], [2] f.; $2^{0}$. Pal. 1682.

19. Tomasz d'Aquine // Encyklopedya powszechna: Część trzecia / wydana pracą i staraniem Adama Wiślickiego. - Warszawa: Nakładem Redakcyi Przeglądu Tygodniowego, 1875. - S. 678. Шифр: I3 пол. B139/3 (N-Zyw).

20. Tomasz z Akwinu // Encyklopedia Powszechna: Tom XIV / Orgelbrand S. Warszawa: Wydawnictwo Towarzystwa Akcyjnego Odlewni Czcionek I Drukarni S. Orgelbranda Synów, 1903. - S. 522. Шифр: I3 пол. В104/14 (Sow-Trsch).

21. Wais K. Kosmologia ogólna // Biblioteka Dzieł Chrześcijańskich. - [Warszawa: Skład Głowny w Ksiegarni Gebethnera i Wolffa]. - 1907. - Zeszyt 74. - S. 14-15.

22. Wais K. Psychologia: Tom I // Biblioteka Dzieł Chrześcijańskich. - [Warszawa: Skład Głowny w Ksiegarni Gebethnera i Wolffa]. - 1902. - Zeszyt Styczeń 1902. - S.33-35, S.54.

23. Wais K. Psychologia: Tom II // Biblioteka Dzieł Chrześcijańskich. - [Warszawa: Skład Głowny w Ksiegarni Gebethnera i Wolffa]. - 1902. - Zeszyt 15. - S. 153, S. 165 , S. 168, S. 185.

24. Wasmann E. Biologia nowoczesna a teorya rozwoju: Cześć I // Biblioteka Dzieł Chrześcijańskich. - [Warszawa: Skład Głowny w Ksiegarni Gebethnera i Wolffa]. - 1913. - Zeszyt 154. - S. 11-12.

25. Правила составления библиографического описания старопечатных 
изданий / Рос. Гос. б-ка; Сост. И.М.Полонская, Н.П.Черкашина. - 2-е изд. перераб. и доп. / Науч. Ред. Н.П.Черкашина - М., 2003. - 400 с. (С.212-213) (описание сериального документа, состоящее из одной общей части (одноуровневое)).

Лямець А.М., Якубова Т.А. Матеріали про Фому Аквінського (1225 або 1226-1274) у польськомовному та франкомовному фондах Відділу бібліотечних зібрань та історичних колекцій НБУВ.

Стаття присвячена книгознавчим та філософським аспектам вивчення спадщини Фоми Аквінського - видатного середньовічного філософа та теолога. Проаналізовано джерела польського фонду Відділу бібліотечних зібрань та історичних колекцій НБУВ, в яких розглядається різнобічна наукова діяльність Святого Фоми. 3 філософського погляду досліджено його роль у примиренні концептів наука та релігія, діалектика та схоластика, логіка та божественне одкровення, давньогрецька філософія та ортодоксальна католицька теологія.

Ключові слова: книгознавство, Фома Аквінський, філософія, теологія, релігія.

Лямеи А., Якубова Т. Материаль о Фоме Аквинском (1225 или 12261274) в польском и франиузском фондах Отдела библиотечных собраний и исторических коллекиий НБУВ.

Статья посвящена книговедческим и философским аспектам изучения наследия Фомы Аквинского - известного средневекового философа и теолога. Проанализированы источники польского фонда Отдела библиотечных собраний и исторических коллекций НБУВ, в которых рассматривается разносторонняя научная деятельность Святого Фомы. С философской точки зрения исследована его роль в примирении концептов - наука и религия, диалектика и схоластика, логика и божественное откровение, древнегреческая философия и ортодоксальная католическая теология.

Ключевые слова: книговедение, Фома Аквинский, философия, теология, религия.

Lyamets A., Yakubova T. Materials about Thomas Aquinas (1225 or 1226-1274) from the polish and french collections of the Library and historical collections department of V.I. Vernadsky National Library of Ukraine.

The article is devoted to book science and philosophical aspects of the study on Thomas Aquinas - a famous medieval philosopher and theologian. The resources from the polish collections of the Library and historical collections department, which are reviewing many-sided research activities of St. Thomas, have been analyzed. From the philosophical point of view, his role in conciliation of such concepts as science and religion, dialectics and scholasti- 
cism, logic and Opus Dei, ancient Greek philosophy and orthodox catholic theology has been studied. In Ukraine the name of Thomas Aquinas is wellknown. The famous historical figure of thomism founder, whose doctrine nowdays has been transformed in neo-scholasticism, remains till the present day actual in book and information science, historical, philosophic, theological research. His teaching and teological activity has been esteemed in wide secular circles in Europe, namely in Cologne, Paris, Rome. The rationalistic views of the theologian, regarding theological questions explanation, have gone far beyond his epoch.

Key words: library science, Thomas Aquinas, philosophy, theology, religion. 